\title{
In situ TEM study of the coarsening of carbon black supported Pt nanoparticles in hydrogen
}

Simonsen, Søren Bredmose; Wang, Yan; Jensen, Jens Oluf; Zhang, Wenjing (Angela)

Published in:

Electrochemical Society. Meeting Abstracts (Online)

Publication date:

2017

Document Version

Publisher's PDF, also known as Version of record

Link back to DTU Orbit

Citation (APA):

Simonsen, S. B., Wang, Y., Jensen, J. O., \& Zhang, W. (2017). In situ TEM study of the coarsening of carbon black supported Pt nanoparticles in hydrogen. Electrochemical Society. Meeting Abstracts (Online), MA2017-02 , [1433]. http://ma.ecsdl.org/content/MA2017-02/32/1433.abstract?sid=7d22f381-06cc-4cd6-ab50-980f863bd550

\section{General rights}

Copyright and moral rights for the publications made accessible in the public portal are retained by the authors and/or other copyright owners and it is a condition of accessing publications that users recognise and abide by the legal requirements associated with these rights.

- Users may download and print one copy of any publication from the public portal for the purpose of private study or research.

- You may not further distribute the material or use it for any profit-making activity or commercial gain

- You may freely distribute the URL identifying the publication in the public portal 


\section{In situ TEM study of the coarsening of carbon black supported Pt nanoparticles in hydrogen}

S.B. Simonsen ${ }^{1 *}$, Yan Wang ${ }^{2}$, J.O. Jensen ${ }^{1}$, Wenjing Zhang ${ }^{1}$

${ }^{1}$ DTU Energy, Frederiksborgvej 399, DK-4000 Roskilde, Denmark

${ }^{2}$ Huaihai Institution of Technology, 222005 Lianyungang City, China

*corresponding author: S.B. Simonsen, e-mail: sobrs @dtu.dk, Phone: +45 20120611

The control of sizes and shapes of nanostructures is of tremendous importance for the catalytic activity in electrochemistry and in catalysis more generally. However, due to relatively large surface free energies, nanostructures often sinter to form coarser and more stable structures that may not have the intended physicochemical properties.

Pt is known to be a very active catalyst in several chemical reactions and for example as carbon supported nanoparticles in fuel cells.

The presentation focusses on coarsening mechanisms of Pt nanoparticles supported on carbon black during exposure to hydrogen. By means of in situ transmission electron microscopy (TEM), Pt nanoparticle coarsening was monitored in 6 mbar $20 \% \mathrm{H}_{2} / \mathrm{Ar}$ while ramping up the temperature to ca. $900{ }^{\circ} \mathrm{C}$. Time-resolved TEM images directly reveal that separated ca. $3 \mathrm{~nm}$ sized Pt nanoparticles in the pure hydrogen environment are stable during constant temperature ramping by $10^{\circ} \mathrm{C} / \mathrm{min}$ up to ca. $800^{\circ} \mathrm{C}$. The coarsening above this temperature is fully dominated by the particle migration and coalescence mechanism. This is contrary to supported Pt nanoparticles in oxygen, where the coarsening is fully dominated by Ostwald ripening. For agglomerated Pt nanoparticles, coalescence events were observed already at ca. 200 ${ }^{\circ} \mathrm{C}$. The temperature-dependency of particle sizes and the observed migration distances are consistent with simple early models for the migration and coalescence. 